\title{
Machinable glass-ceramics forming as a restorative dental material
}

\author{
Duangrudee CHAYSUWAN ${ }^{1,2}$, Krongkarn SIRINUKUNWATTANA ${ }^{1}$, Kanchana KANCHANATAWEWAT ${ }^{3}$, \\ Greg HENESS ${ }^{4}$ and Kimihiro YAMASHITA ${ }^{5}$
}

\begin{abstract}
${ }^{1}$ Department of Materials Engineering, Faculty of Engineering, Kasetsart University, 50 Ngamwongwan Rd., Ladyao, Chatuchak, Bangkok, 10900 Thailand

${ }^{2}$ Materials Innovation Center, Faculty of Engineering, Kasetsart University, 50 Ngamwongwan Rd., Ladyao, Chatuchak, Bangkok, 10900 Thailand ${ }^{3}$ Institute of Advanced Dental Medicine, Rangsit University, Vanit 2 Bld., New Petchaburi Rd., Makkasan, Bangkok, 10400 Thailand ${ }^{4}$ Department of Physics and Advanced Materials, Faculty of Science, University of Technology, Sydney, PO Box 123 Broadway, NSW 2007 Australia 5Institute of Biomaterials and Bioengineering, Tokyo Medical and Dental University, 2-3-10 Kanda-Surugadai, Chiyoda-ku, Tokyo 101-0062 Japan Corresponding author, Duangrudee CHAYSUWAN; E-mail: fengddc@ku.ac.th
\end{abstract}

\begin{abstract}
$\mathrm{MgO}, \mathrm{SiO}_{2}, \mathrm{Al}_{2} \mathrm{O}_{3}, \mathrm{MgF}_{2}, \mathrm{CaF}_{2}, \mathrm{CaCO}_{3}, \mathrm{SrCO}_{3}$, and $\mathrm{P}_{2} \mathrm{O}_{5}$ were used to prepare glass-ceramics for restorative dental materials. Thermal properties, phases, microstructures and hardness were characterized by DTA, XRD, SEM and Vickers microhardness. Three-point bending strength and fracture toughness were applied by UTM according to ISO 6872: 1997(E). XRD showed that the glass crystallized at $892^{\circ} \mathrm{C}$ (second crystallization temperature $+20^{\circ} \mathrm{C}$ ) for $3 \mathrm{hrs}$ consisted mainly of calcium-mica and fluorapatite crystalline phases. Average hardness $(3.70 \mathrm{GPa})$ closely matched human enamel $(3.20 \mathrm{GPa})$. The higher fracture toughness $(2.04 \mathrm{MPa} \sqrt{\mathrm{m}})$ combined with the hardness to give a lower brittleness index $\left(1.81 \mu \mathrm{m}^{-1 / 2}\right)$ which indicates that they have exceptional machinability. Bending strength results $(176.61 \mathrm{MPa})$ were analyzed by Weibull analysis to determine modulus value $(m=17.80)$. Machinability of the calcium micafluorapatite glass-ceramic was demonstrated by fabricating with CAD/CAM.
\end{abstract}

Keywords: CAD/CAM technique, Calcium mica-fluorapatite glass-ceramic, Restorative dental material, Brittleness index, ISO 6872 : 1997(E)

\section{INTRODUCTION}

The use of all-ceramic materials for fixed restorations in dentistry has become increasingly important due to their aesthetics, biocompatibility, high abrasion resistance, high wear resistance, chemical inertness and both thermal and electrical insulation ${ }^{1,2)}$. However, their hardness and brittleness affect their fabrication capabilities. Due to the small size of dental restorations, it is necessary to be able to fabricate them with high accuracy and precision. Computer aided design and computer aided manufacturing (CAD/CAM) technology provides dentists with the ability to do this for the often complex shapes of these restorative dental ceramics. This technology is replacing the traditional lost wax casting technique with a resultant decrease in manufacturing time ${ }^{3}$. CAD/CAM systems, however, utilize abrasive (grinding and milling) processes, and therefore, ceramics used with this technique need to possess excellent machinability ${ }^{3)}$.

Currently, most restorative ceramic materials used with CAD/CAM systems are based on leucite $\left(\mathrm{K}_{2} \mathrm{Al}_{2} \mathrm{Si}_{4} \mathrm{O}_{12}\right)$. However, because of its high hardness and high abrasiveness, machining results in high tool wear and, in use, causes wear of the opposing teeth ${ }^{4}$.

Machinability is an important property of mica-based glass-ceramics. It arises from the weak bonding between the mica layers resulting in a perfect basal cleavage ${ }^{5,6}$. Hence, mica-based glass-ceramics lend themselves for use with $\mathrm{CAD} / \mathrm{CAM}$ systems. Alkali-containing trisilicic

Color figures can be viewed in the online issue, which is available at J-STAGE.

Received Sep 13, 2010: Accepted Feb 8, 2011

doi:10.4012/dmj.2010-154 JOI JST.JSTAGE/dmj/2010-154 and fluorophlogopite-type mica were first reported by Beall ${ }^{7}$. Macor $^{\circledR}$ is a well known mica glass-ceramic developed by Corning Glass. Its chemical composition was based on $\mathrm{K}_{2} \mathrm{O}-\mathrm{MgO}-\mathrm{B}_{2} \mathrm{O}_{3}-\mathrm{Al}_{2} \mathrm{O}_{3}-\mathrm{SiO}_{2}-\mathrm{F}$ system, of which the main crystalline phase was fluorophlogopite, $\mathrm{KMg}_{3}\left(\mathrm{AlSi}_{3} \mathrm{O}_{10}\right) \mathrm{F}_{2}{ }^{7}$. Subsequently, Hoda and Beall ${ }^{8)}$ investigated the different nonalkali mica glass-ceramics containing barium, calcium, and strontium in the system of alkali earth oxide- $\mathrm{Al}_{2} \mathrm{O}_{3}-\mathrm{SiO}_{2}-\mathrm{F}$. These glass-ceramics had excellent dielectric properties, high mechanical strength and refractoriness. The structural formula of mica is generally expressed as $\mathrm{X}_{0.5-1} \mathrm{Y}_{2-3} \mathrm{Z}_{4} \mathrm{O}_{10}(\mathrm{OH}, \mathrm{F})_{2}$, where $\mathrm{X}, \mathrm{Y}$, and $\mathrm{Z}$ are cations in 12-, 6-, and 4-fold coordinations respectively ${ }^{8}$.

Uno et al. ${ }^{9)}$ investigated glasses from the ternary system of $\mathrm{Ba}_{0.5} \mathrm{Mg}_{3}\left(\mathrm{Si}_{3} \mathrm{AlO}_{10}\right) \mathrm{F}_{2}-\mathrm{Ca}_{3}\left(\mathrm{PO}_{4}\right)_{2}-\mathrm{Mg}_{2} \mathrm{Al}_{4} \mathrm{Si}_{5} \mathrm{O}_{18}$ and found that, in agreement with Chaysuwan et al. ${ }^{10}$, bending strength and fracture toughness were improved over that of Macor ${ }^{\circledR}$. Hardness and biaxial flexural strength of these glass-ceramics were twice those of Macor $^{\circledR}$, however, machinability was worse than that of Macor $^{\circledR}$.

The recent work of Chaysuwan et al. ${ }^{11)}$ described the introduction of $\mathrm{Sr}^{2+}$ to the interlayer ions of the mica structure instead of $\mathrm{Ba}^{2+}$, giving an initial composition close to a $\mathrm{Sr}_{0.5} \mathrm{Mg}_{3}\left(\mathrm{Si}_{3} \mathrm{AlO}_{10}\right) \mathrm{F}_{2}-\mathrm{Ca}_{5}\left(\mathrm{PO}_{4}\right)_{3} \mathrm{~F}-\mathrm{Mg}_{2} \mathrm{Al}_{4} \mathrm{Si}_{5} \mathrm{O}_{18}$ stoichiometry. They found that the hardness of the crystallized glass-ceramics for the second crystallized temperature of heat treatments was similar to human enamel whilst the strength was also low. Keawsupsak et $a l .{ }^{12)}$ introduced fluorapatite $\left(\mathrm{Ca}_{5}\left(\mathrm{PO}_{4}\right)_{3} \mathrm{~F}\right)$ into this glassceramic system so as to increase the flexural strength 
and found that both strength and fracture toughness increased with increasing amounts of fluorapatite up to a fluorapatite content of not more than $4 \mathrm{~mol} \%$. This investigation describes the fabrication of glass-ceramics based on this $4 \mathrm{~mol} \%$ of fluorapatite (GCF 4.0) for restorative dental materials via CAD/CAM using CEREC 3 software.

\section{MATERIALS AND METHODS}

\section{Glass preparation}

The glasses were produced by melting $\mathrm{MgO}, \mathrm{SiO}_{2}, \mathrm{Al}_{2} \mathrm{O}_{3}$, $\mathrm{MgF}_{2}, \mathrm{CaF}_{2}, \mathrm{CaCO}_{3}, \mathrm{SrCO}_{3}$, and $\mathrm{P}_{2} \mathrm{O}_{5}$ in high density alumina crucibles at a temperature of $1,420^{\circ} \mathrm{C}$ in a high temperature furnace (Nabertherm, HT 16/18, Lilienthal, Germany, $\max .1,800^{\circ} \mathrm{C}$ ) for $2 \mathrm{hrs}$ with heating rate of $10^{\circ} \mathrm{C} / \mathrm{min}$. A batch size of approximately $100 \mathrm{~g}$ was used. The resultant chemical composition of the glass batch prepared had a weight ratio close to $4 \mathrm{~mol} \%$ of fluorapatite and $90 \mathrm{~mol} \%$ of mica and is shown in Table $1^{11,12)}$. The melts were rapidly quenched into water to prevent phase separation and crystallization ${ }^{4}$. The obtained glasses (glass frit) were remelted and poured into a carbon mould to yield a glass rod or cylinder. The obtained glass rod was then immediately transferred to an annealing furnace (Linn High Therm, LM 512, Eschenfelden, Germany, $\max .1,200^{\circ} \mathrm{C}$ ) operating at approximately $50^{\circ} \mathrm{C}$ below their glass-transition temperature $\left(\mathrm{T}_{\mathrm{g}}-50^{\circ} \mathrm{C}\right)$ for $2 \mathrm{hrs}$ followed by slow cooling to room temperature in the furnace.

\section{Glass characterization}

1. Differential thermal analysis (DTA)

The glasses were characterized by differential thermal analysis using a Perkin Elmer TAC7/DX (Perkin Elmer, DTA7, Massachusetts, USA). Glass frits were crushed and sieved through a 325 mesh ( $<45$ micrometer) to obtain glass powder suitable for thermal analysis. Each scan was from ambient temperature to $1,200^{\circ} \mathrm{C}$ and $\alpha-\mathrm{Al}_{2} \mathrm{O}_{3}$ powder was used as the reference material.

Optimum nucleation temperatures were determined by the Marrotta method ${ }^{13)}$ with one hour holding for nucleation. Suitable heat treatment times were determined using these nucleation temperatures and were held at various length of times $(0.5,1,2,4$, and 10 hours).

DTA was performed by heating samples at a heating rate of $5,10,15$, and $20^{\circ} \mathrm{C} / \mathrm{min}$ to the optimum nucleation temperature and held for one hour. Samples were also heated from ambient to $1,000^{\circ} \mathrm{C}$ in order to calculate the activation energy by the Kissinger equation ${ }^{14)}$ in Eq. (1) and the Avrami exponent by Augis-Bennett equation ${ }^{15}$ in Eq. (2).

The Johnson-Mehl-Avrami equation (J.M.A.) ${ }^{16)}$ was applied to describe the behavior of the non-isothermal crystallization kinetics of glass developed by Kissinger ${ }^{13)}$ as Eq. (1):

$$
\ln \frac{T_{p}^{2}}{\alpha}=\frac{E}{R T_{p}}+\text { constant }
$$

where $T_{p}$ is the crystallization peak (Fig. 2), $\alpha$ is the heating rate $(\mathrm{K} / \mathrm{min}), E$ is the activation energy $(\mathrm{J} / \mathrm{mol})$ and $R$ is the universal gas constant ( $8.314 \mathrm{~J} / \mathrm{mol} . \mathrm{K})$.

Using the value of the activation energy, the Avrami exponent ( $n$ ) was calculated by the Augis-Bennett equation $^{15)}$ as in Eq. (2):

Table 1 The composition of the glass ${ }^{11,12)}$

\begin{tabular}{lcccccccccc}
\hline Compound & $\mathrm{MgO}$ & $\mathrm{SiO}_{2}$ & $\mathrm{Al}_{2} \mathrm{O}_{3}$ & $\mathrm{MgF}_{2}$ & $\mathrm{CaF}_{2}$ & $\mathrm{CaCO}_{3}$ & $\mathrm{SrCO}_{3}$ & $\mathrm{P}_{2} \mathrm{O}_{5}$ \\
\hline Concentration $(\mathrm{mol} \%)$ & 26.09 & 40.76 & 7.74 & 12.23 & $\mathrm{x}$ & $\mathrm{y}$ & 6.11 & $\mathrm{z}$ \\
\hline
\end{tabular}

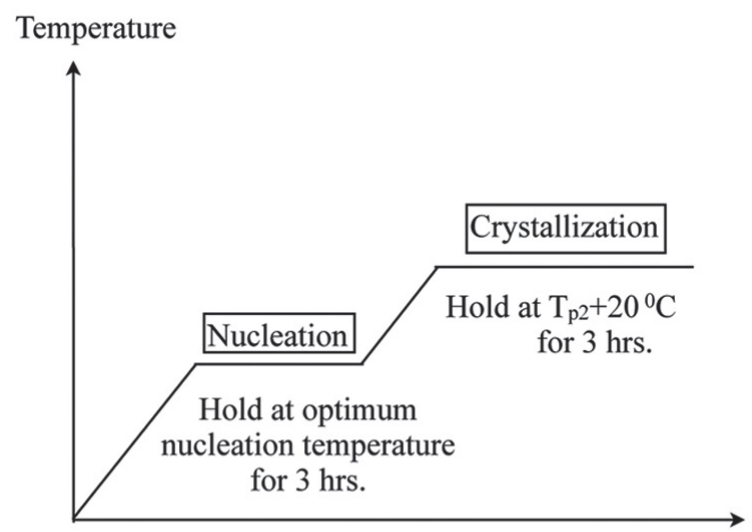

Time

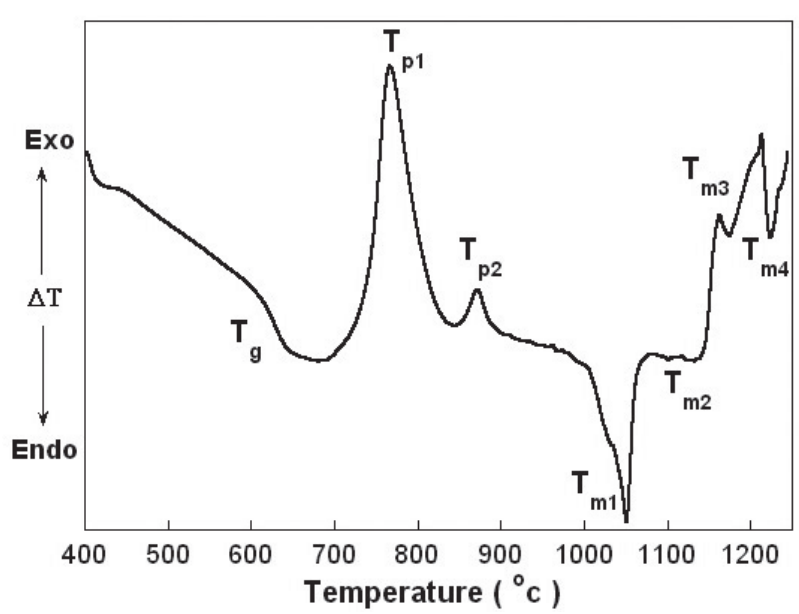

Fig. 2 DTA curve of the glass-ceramic

Fig. 1 Schematic of heat treatment process 


$$
n=2.5 \frac{R T_{p}^{2}}{\Delta T E}
$$

where $\Delta T$ is the interval temperature on the half height point of crystallization peak. The value of the Avrami exponent $(n)$ is a parameter related to the crystallization mechanisms: for $n=1$, the crystallization mechanism is one of surface crystallization; for $n=2$, the mechanism is two-dimensional growth; and for $n=3$, three-dimensional growth $^{17)}$.

\section{Glass-ceramics preparation}

Both the glass rods and frit were crystallized via a heat treatment process outlined by Marotta ${ }^{13)}$. The heat treatment process converts glass to glass-ceramics by two individual processes, nucleation and crystal growth ${ }^{13)}$. Glass rods were heated at the constant heating rate of $10^{\circ} \mathrm{C} / \mathrm{min}$ to the optimum nucleation temperature and held there for 3 hrs (Fig. 1). They were then heated up at the same heating rate to allow crystal growth at the second peak of crystallization plus $20^{\circ} \mathrm{C}\left(\mathrm{T}_{\mathrm{p} 2}+20^{\circ} \mathrm{C}\right)$ and held for $3 \mathrm{hrs}$ heat treatment time. The obtained glass-ceramics based on this $4.0 \mathrm{~mol} \%$ of fluorapatite was called GCF 4.0. Fig. 2 shows two exothermic peaks, denoted by $\mathrm{T}_{\mathrm{p} 1}$ and $\mathrm{T}_{\mathrm{p} 2}$, representing the first crystallization temperature and the second crystallization temperature, respectively.

\section{Characterization techniques}

1. X-ray powder diffraction (XRD)

A Philips powder diffractometer (Philips, X'pert PW 3040/00, Eindhoven, The Netherlands) was used with $\mathrm{Cu}$ $\mathrm{K}_{\alpha}$ X-rays. Heat-treated frits were ground to a fine powder for analysis by X-ray diffraction. Scan parameters were a step size of $0.05^{\circ}$, a count time of $0.5 \mathrm{~s}$, and operating at $40 \mathrm{kV}$ and $30 \mathrm{~mA}$.

2. Scanning electron microscopy (SEM)

Microstructure was observed on surfaces which were polished to 1 micrometer and fracture surfaces of mechanical-tested specimen by scanning electron microscope (Philips, XL30\&EDAX, Eindhoven, the Netherlands). Prior to SEM analysis, surfaces were chemically etched using $10 \%$ hydrofluoric acid solution for $20 \mathrm{~s}$ then rinsed with water and sonicated to remove debris. No etching was performed on fracture surfaces. After cleaning, the samples were gold sputtering.

\section{Mechanical testing}

\section{Vickers hardness}

Vickers microhardness (Shimadzu, HMV-2000, Kyoto, Japan) was performed with a pyramid-shaped diamond indenter at a load of $500 \mathrm{~g}$ for $15 \mathrm{~s}$. The thickness of specimens was $3 \mathrm{~mm}$.

2. Three point bending strength

Glass-ceramic rods were cut into bars of $4 \times 3 \times 40 \mathrm{~mm}^{3}$. The edge chamfer specified for strength test was ignored $^{17)}$. They were then ground and polished to 1 micrometer. Ten bar specimens of each were tested by a universal testing machine (Instron, 8872, Massachusetts,
USA) according to ISO 6872: 1997(E ${ }^{18)}$ using three-point geometry. A cross-head speed of $0.5 \mathrm{~mm} / \mathrm{min}$ was used in order to avoid subcritical crack growth during the experiment. The strength distribution was analyzed by Weibull distribution (ISO 6872: 1997(E) ${ }^{18)}$ ), using the following equation:

$$
\ln \ln \left(\frac{1}{1-P_{f}}\right)=m \ln \sigma_{\mathrm{c}}-m \ln \sigma_{\mathrm{c}, 0}
$$

where $P_{f}$ is the probability of failure, $\sigma_{c}$ is the strength, $\sigma_{c, 0}$ is the characteristic strength (at $63 \%$ failure probability) and $m$ is the Weibull modulus.

The failure probability was calculated assuming the following relation : $P_{f}=(i-0.5 / N)$ where $P_{f}$ is the failure probability of the $i^{\text {th }}$ specimen (ranked in order of ascending strength) and $N$ is the total number of specimens tested.

\section{Fracture toughness}

Fracture toughness $\left(K_{I C}\right)$ values were obtained using Single Edge V-Notch Beam (SEVNB) method. Ten bar specimens in size of $3 \times 2 \times 25 \mathrm{~mm}^{3}$ in accordance with ISO 6872: $1997(\mathrm{E})^{18)}$ were tested by a universal testing machine (Instron, 8872, Massachusetts, USA) applying cross-head speed of $0.5 \mathrm{~mm} / \mathrm{min}$.

4. Machinability

The machinability can be simply measured when a material is cut, however, quantitative measurement is difficult depending on various criteria such as measuring tool wear, surface roughness and cutting force ${ }^{19,20)}$. Boccaccini $^{20)}$ determined a brittleness index $(B)$ as a parameter for estimating the machinability of glassceramics given by the ratio of hardness $(H v)$ to fracture toughness $\left(K_{I C}\right)($ Eq. (4)):

$$
B=\frac{H v}{K_{I C}}
$$

The lower the brittleness index, the higher the machinability.

\section{CAD/CAM Fabrication}

Prior to sand milling of glass-ceramic blocks, they were cut from glass-ceramic rods to a size of $10 \times 12 \times 15 \mathrm{~mm}^{3}$ and ground with grit size $8.4 \mu \mathrm{m}$ of $\mathrm{SiC}$ paper. Consequently, they were then adhered to stainless steel abutments by Super-Bond C\&B which is a self-cure dental adhesive resin cement ${ }^{21}$. The CEREC 3D software (V2.10 R1500) is used for designing inlay, veneer, premolar crown and molar crown restorations. The default milling mode and the default milling burs (CEREC Cone-shaped Cylinder Diamond 1.6, Art.No.58 55734 D3329, CEREC Cylinder Diamond 1.6, Art. No. 5466193b D3268, Sirona Dental Systems GmbH, Bensheim, Germany) were used to mill the glass-ceramic blocks.

\section{Roughness measurement by stylus profiler}

After fabricating, specimens were sonicated with acetone to remove debris. Then, for each specimen, the roughness 
(a)
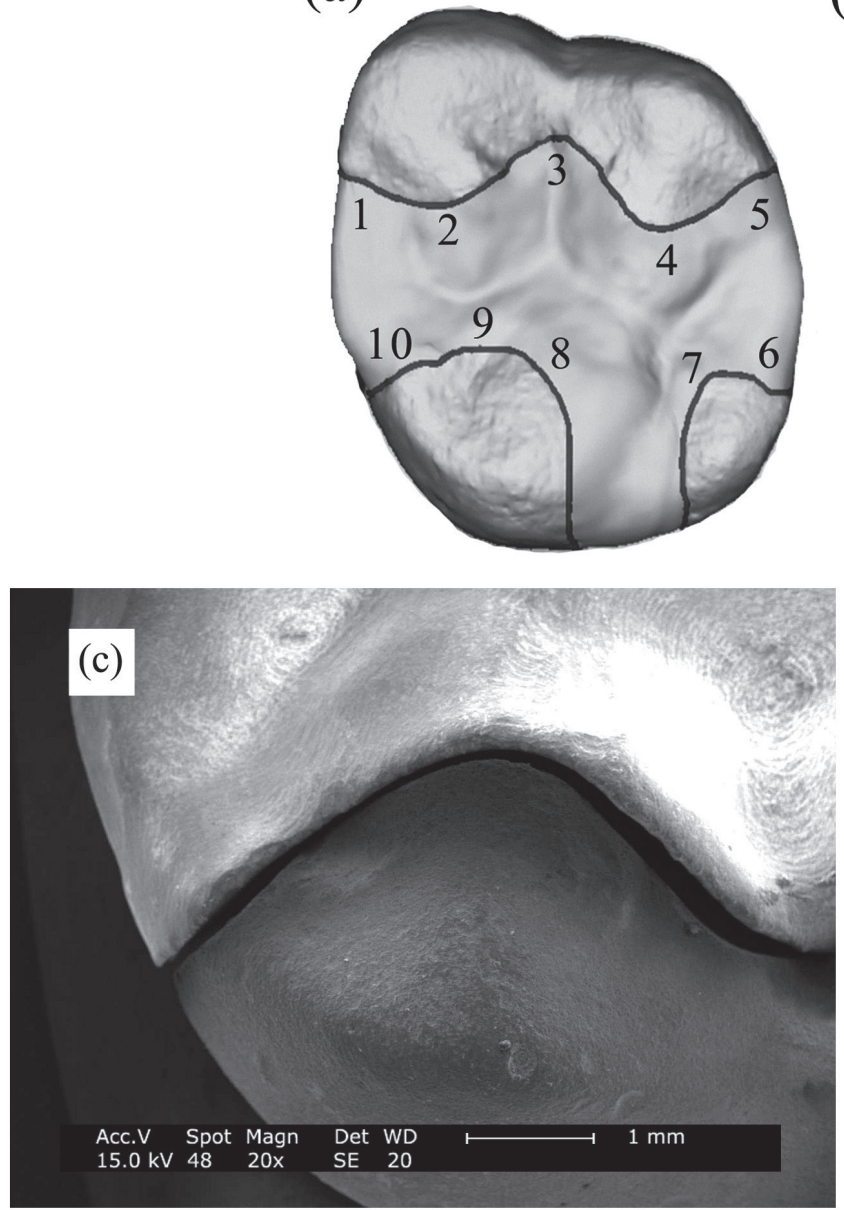

(b)
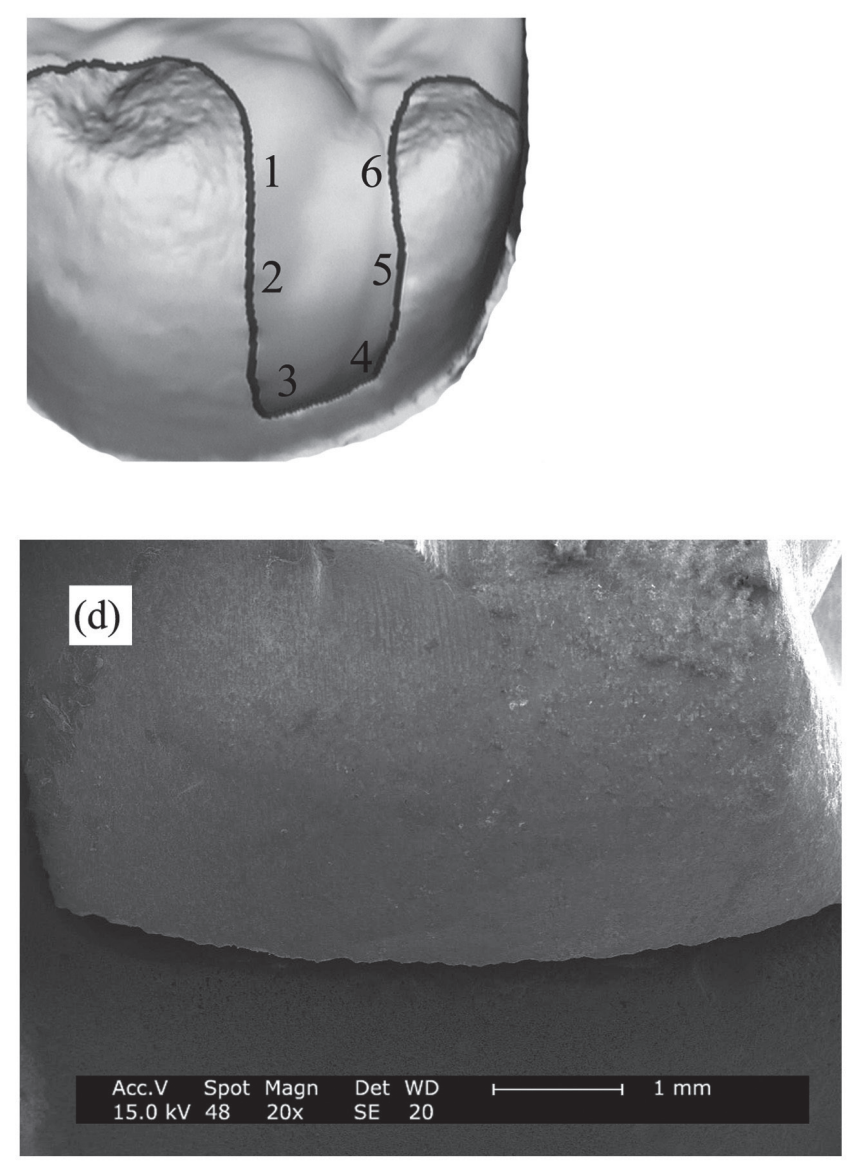

Fig. 3 (a) measured location along occlusal margins, (b) measured location along interproximal margins, (c) SEM of occlusal surface and (d) interproximal surface

was measured three times by a stylus profiler (TaylorHobson, Leicester, United Kingdom). The surface contact length was $3.2 \mathrm{~mm}$ in orthogonal directions.

\section{Margin gap size of occlusal and interproximal surface of inlay \\ Fit at the margin of the inlay was evaluated in terms of the average marginal gap of the occlusal surface and interproximal surface. The margin gaps were measured in 10 locations along the occlusal margins (Fig. 3a) and 6 locations along interproximal margins (Fig. 3b). The photographs were taken perpendicular to the surface along the margin gap using scanning electron microscopy (Figs. 3c and 3d).}

\section{RESULTS}

Thermal analysis

1. Differential thermal analysis (DTA)

The DTA curve of the as-quenched glass is shown in Fig. 2 . The glass transition temperature, $\mathrm{T}_{g}$, was given by the endothermic shoulder at approximately $630^{\circ} \mathrm{C}$. The two exothermic peaks at $767^{\circ} \mathrm{C}$ and $872^{\circ} \mathrm{C}$ are crystallization peaks which were denoted by $\mathrm{T}_{\mathrm{p} 1}$ and $\mathrm{T}_{\mathrm{p} 2}$, respectively. The endothermic peaks above $1,000^{\circ} \mathrm{C}$ are the result of the decomposition, softening, and, probably, melting processes of the different crystalline phases.

Previous investigations ${ }^{11,12}$ indicated that the glassceramics crystallized at a temperature of $20^{\circ} \mathrm{C}$ above the second peak of crystallization $\left(\mathrm{T}_{\mathrm{p} 2}+20^{\circ} \mathrm{C}\right)$ showed hardness resembling human enamel and that the crystallization was complete. Hence, for this research, $\mathrm{T}_{\mathrm{p} 2}+20^{\circ} \mathrm{C}$ was used.

2. Determination of the optimum nucleation temperature and time of heat treatment outlined by Marotta method ${ }^{13)}$ Differential thermal analysis was performed to determine the optimum nucleation temperature and time by collecting $\mathrm{T}_{\mathrm{p} \lambda}$ from each isothermal hold for an hour at $\mathrm{T}_{\mathrm{g}}-30^{\circ} \mathrm{C}, \mathrm{T}_{\mathrm{g}}-15^{\circ} \mathrm{C}, \mathrm{T}_{\mathrm{g}}{ }^{\circ} \mathrm{C}, \mathrm{T}_{\mathrm{g}}+15^{\circ} \mathrm{C}$ and $\mathrm{T}_{\mathrm{g}}+30^{\circ} \mathrm{C}$. Then the graph of holding temperature against $\left(\mathrm{T}_{\mathrm{p} 2 \text { original- }}{ }^{-}\right.$ $\mathrm{T}_{\mathrm{p} 2}^{*}$ ), i.e. the difference temperatures between $\mathrm{T}_{\mathrm{p} 2}$ of as-quenched glass and $\mathrm{T}^{*}{ }^{*}$ of the other holding 

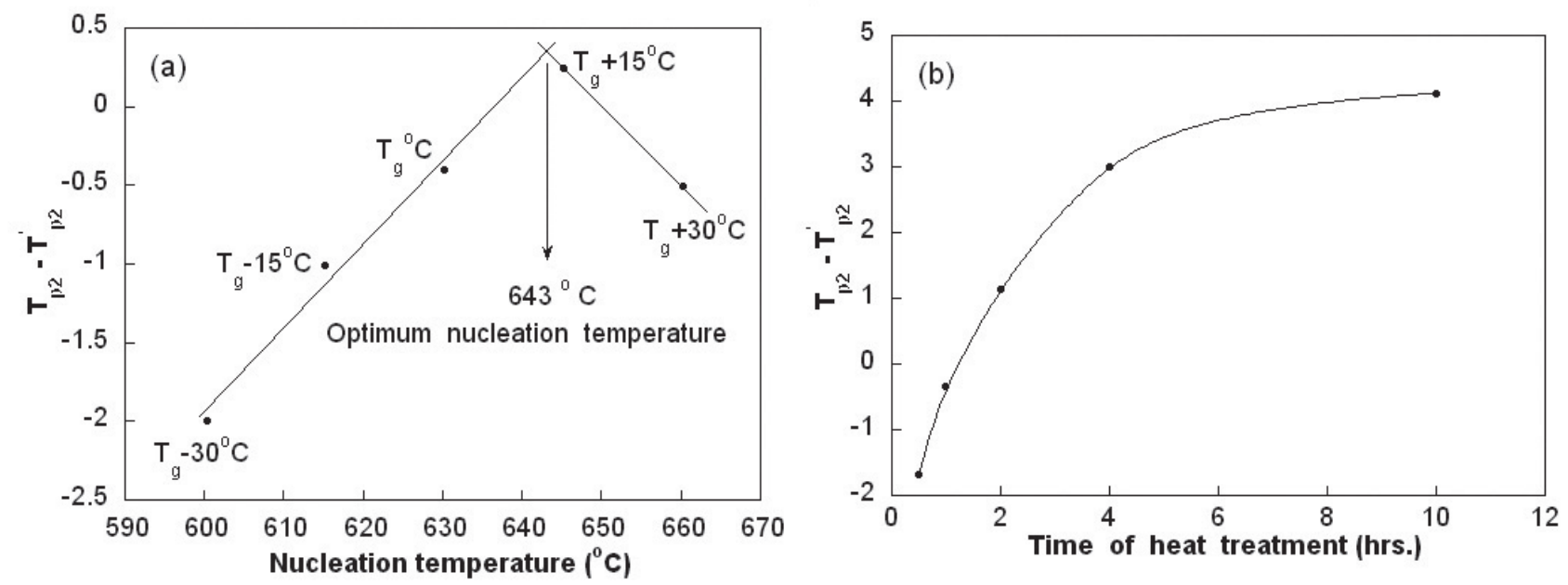

Fig. 4 (a) $\mathrm{T}_{\mathrm{p} 2}-\mathrm{T}^{*}{ }_{\mathrm{p} 2}$ plotted against heat treatment temperature

(b) $\mathrm{T}_{\mathrm{p} 2}-\mathrm{T}_{\mathrm{p} 2}^{*}$ plotted against time of heat treatment

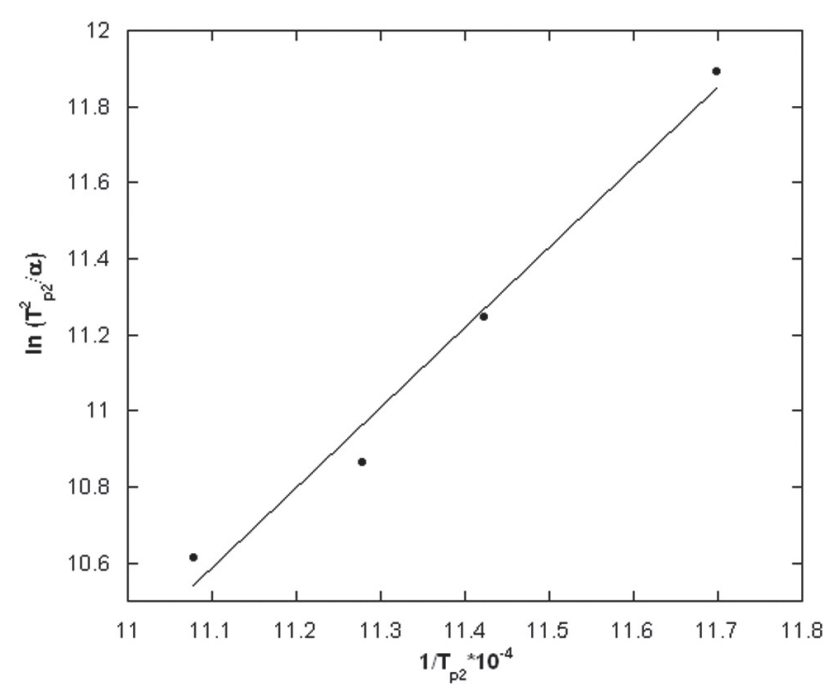

Fig. 5 Plot of $\ln \left(T_{\mathrm{p}}^{2} / \alpha\right)$ vs $1 / T_{p}$

temperatures, were plotted. Fig. 4(a) shows the plots of $\left(\mathrm{T}_{\mathrm{p} 2}-\mathrm{T}_{\mathrm{p} 2}^{*}\right)$ versus holding temperatures for glass ceramic GCF 4.0. The maxima, from where two straight lines drawn through the points intersected provided the optimum nucleation temperature of $643^{\circ} \mathrm{C}$ for this material. Thus, the samples were held for various times at this temperature in order to evaluate optimal time for nucleation duration for the heat treatment ${ }^{13)}$. In Fig. 4(b), plots of $\mathrm{T}_{\mathrm{p} 2}-\mathrm{T}_{\mathrm{p} 2}^{*}$ against the times of heat treatments are presented. It shows that the nuclei number increases rapidly with increasing heat treatment time, similar to that found by Marotta's ${ }^{13)}$. It was found that the maximum number of nuclei occurred at approximate used as the time of heat treatment.

The activation energy $(E)$ for crystallization, derived

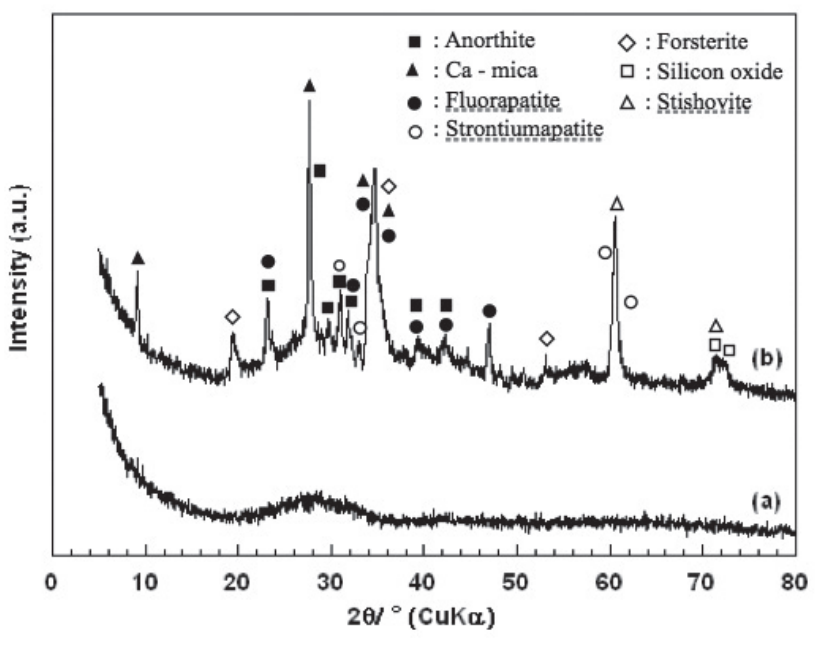

Fig. 6 XRD patterns of: (a) as-received glass (b) a glassceramic crystallized at $892^{\circ} \mathrm{C}$

from the slope $(E / R)$ of the plot of $\ln \left(T_{p}^{2} / \alpha\right)$ against $1 / T_{p}$, was $175.47 \mathrm{~kJ} / \mathrm{mol}$ as shown in Fig. 5. From Eq. (2), the Avrami exponent was approximately 3 indicating that the dominant crystallization mechanism was threedimensional in the bulk.

\section{Crystallization process}

1. X-ray diffraction analysis (XRD)

The changes in intensity of XRD patterns of an as-quenched glass and the glass-ceramic crystallized at $\mathrm{T}_{\mathrm{p} 2}+20^{\circ} \mathrm{C}\left(892^{\circ} \mathrm{C}\right)$ are shown in Fig. 6 . The pattern of the as-received glass shows a fully amorphous material as in Fig. 6(a) whereas Fig. 6(b) shows the patterns of heat-treated sample heated up to a temperature of $892^{\circ} \mathrm{C}$ and soaked at that temperature $3 \mathrm{hrs}$. The predominant 

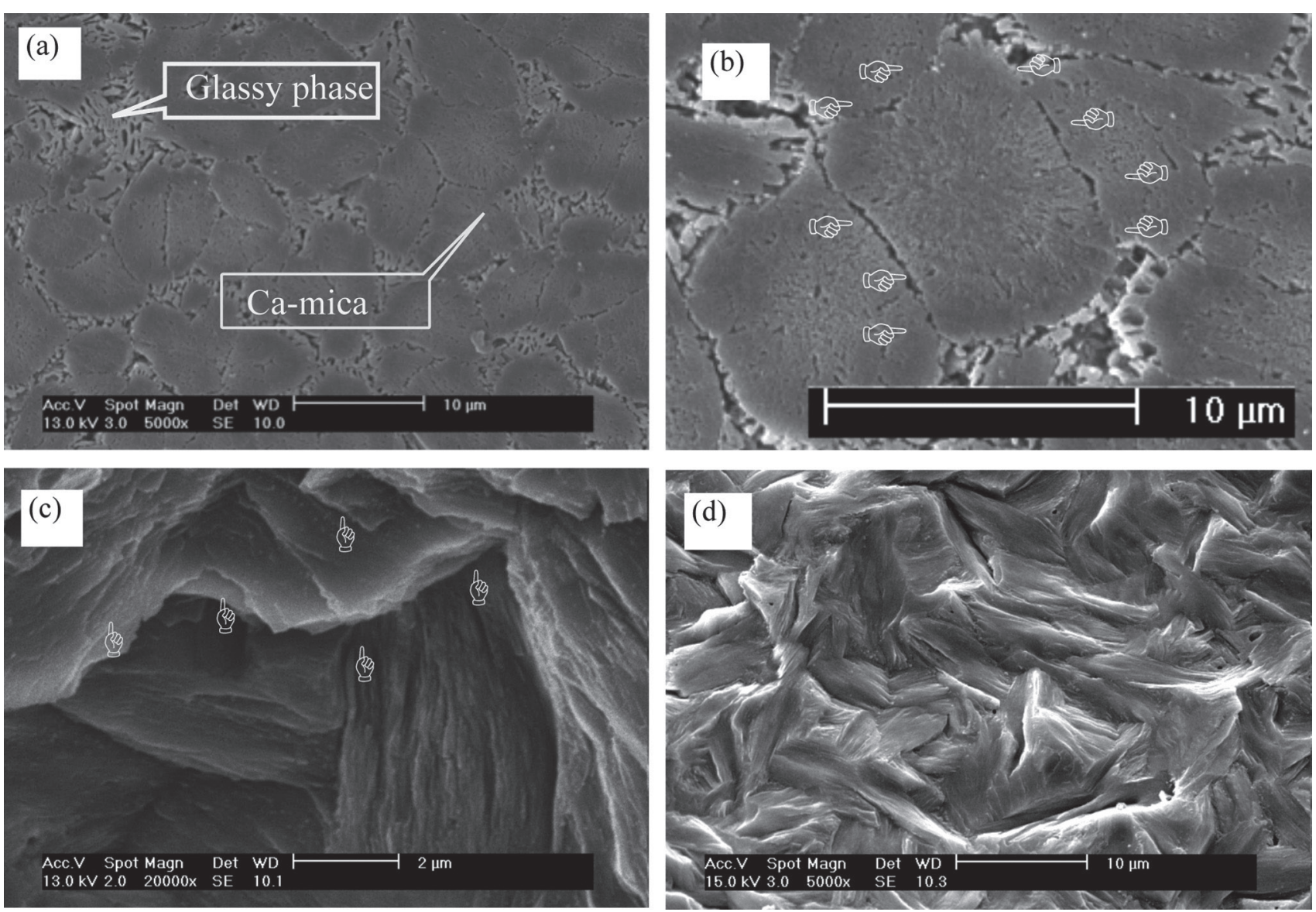

Fig. 7 Microstructures of the polished and etched surface of glass-ceramics crystallized at $892^{\circ} \mathrm{C}$, (a) grains of Ca-mica and glassy phase at grain boundaries, (b) mica grew radially (the fingers indicated interlocking structure), microstructures of the fracture surface without etching (c) the fingers pointed plate-like of Ca-mica microstructure and (d) plate-like microstructures in the bulk

crystalline phases are calcium-mica $\left(\mathrm{Ca}_{0.5} \mathrm{Mg}_{3} \mathrm{AlSi}_{3} \mathrm{O}_{10} \mathrm{~F}_{2}\right)$, fluorapatite $\left(\mathrm{Ca}_{5}\left(\mathrm{PO}_{4}\right)_{3} \mathrm{~F}\right)$ mixed with strontiumapatite $\left(\mathrm{Ca}_{5}\left(\mathrm{PO}_{4}\right)_{3} \mathrm{Sr}\right)$ and anorthite $\left(\mathrm{CaAl}_{2} \mathrm{Si}_{2} \mathrm{O}_{8}\right)$. In addition, forsterite $\left(\mathrm{Mg}_{2} \mathrm{SiO}_{4}\right)$, stishovite $\left(\mathrm{SiO}_{2}\right)$ and silicon oxide $\left(\mathrm{SiO}_{2}\right)$ were the minor crystalline structures. Cordierite $\left(\mathrm{Mg}_{2} \mathrm{Al}_{4} \mathrm{Si}_{5} \mathrm{O}_{18}\right)$ was not observed in specimens of this research. The absence of cordierite is beneficial as it is hard and may result in increased tool wear and is considered an undesirable phase in a machinable glassceramic $^{4}$.

2. Microstructural analysis

The SEM micrograph of the polished and etched surface of optimally heat treated GCF 4.0 is shown in Fig. 7(a). The microstructure is composed of two phases, a glassy phase and a calcium-mica phase. The equiaxed grains of calcium-mica grew radially out from the centre of each grain until meeting at the grain boundaries. An interlocking microstructure of mica was then formed ${ }^{22)}$ as shown in Fig. 7(b). The grain boundaries had a remnant glassy phase, depicted by the chemically attacked area due to the etching with HF. The average grain size of calcium-mica was between 4.0 and 5.7

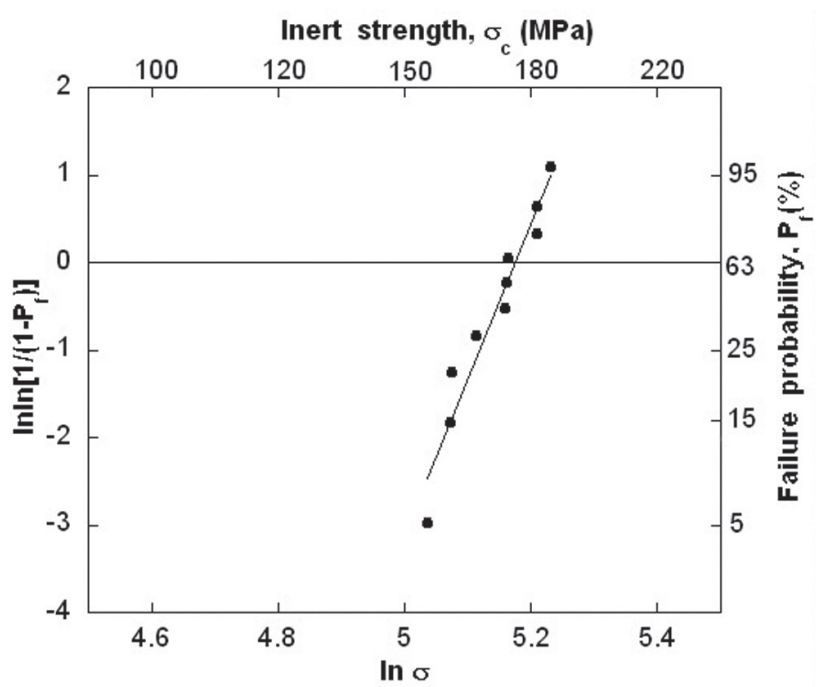

Fig. 8 Weibull distribution for flexural strength 
Table 2 Mechanical properties of the resultant glass-ceramic and human enamel

\begin{tabular}{lcccccc}
\hline & $\sigma_{c, 0}(\mathrm{MPa})$ & $m$ & $H_{v}(\mathrm{GPa})$ & $K_{I C}(\mathrm{MPa} \sqrt{\mathrm{m}})$ & $B\left(\mu \mathrm{m}^{-1 / 2}\right)$ & $\mathrm{Machinability}$ \\
\hline GCF 4.0 & 176.61 & 17.80 & $3.70 \pm 0.24$ & $2.04 \pm 0.30$ & $1.81 \pm 0.29$ & 0 \\
Human enamel $^{3)}$ & - & - & $3.20 \pm 0.40$ & $0.77 \pm 0.05$ & $4.15 \pm 0.58$ & 0 \\
$2 \mathrm{~A} 8 \mathrm{M}^{22}$ & 139 & - & 2.8 & - & - & 0 \\
$3 \mathrm{~A} 7 \mathrm{M}^{22}$ & 204 & - & 4.8 & - & - & $\times$ \\
\hline
\end{tabular}

Remark: A and M are the stoichiometric fluorapatite and calcium-mica, respectively.

O stands for "good machinability"; × stands for "no good machinability".

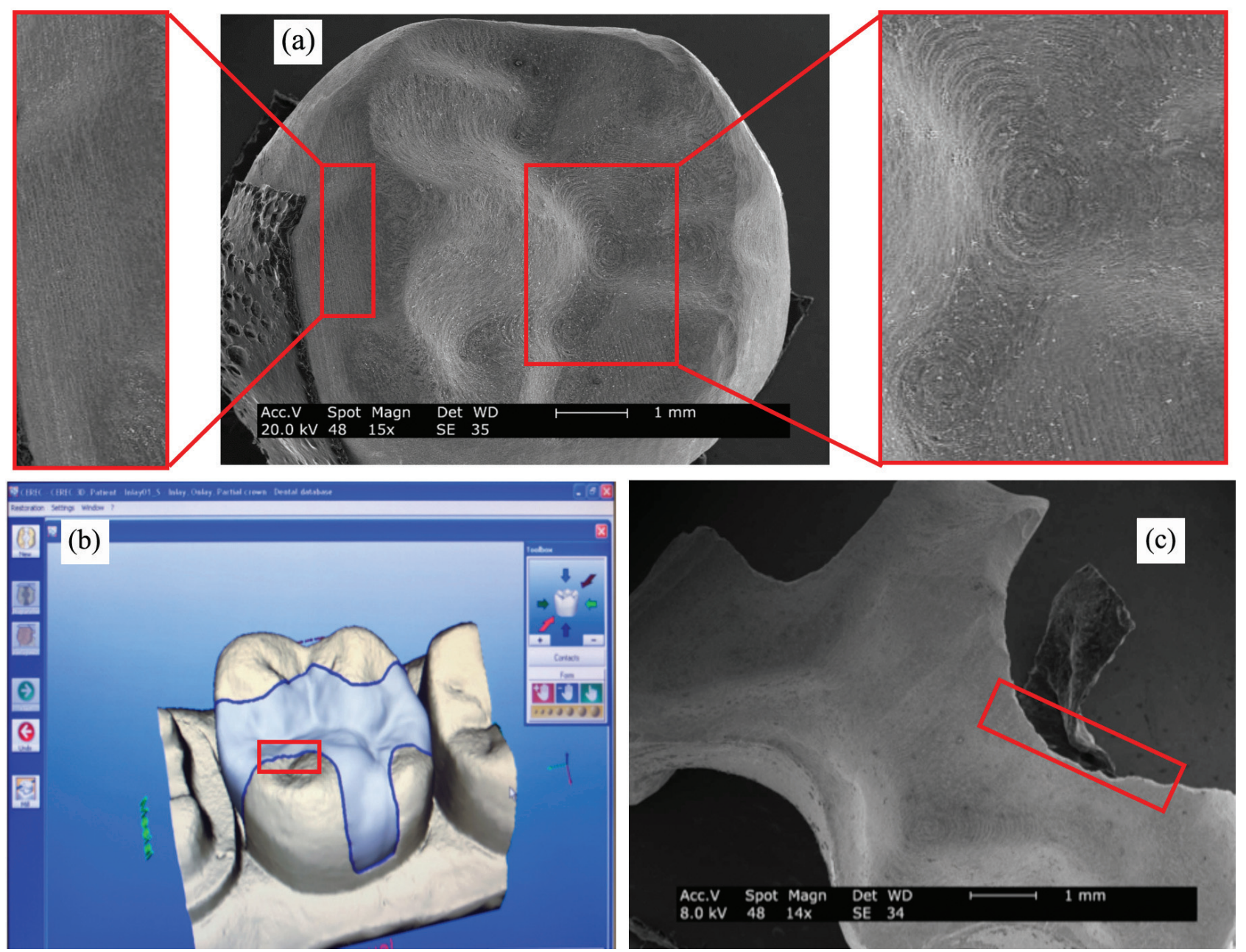

Fig. 9 (a) SEM of crown (15×) with magnification of strip lines, (b) reveals the designed inlay and (c) the duplicated inlay

micrometer (Intercept method ASTM E112 standard $^{23)}$ ). Ca-mica crystals on the fracture surface consist of layers of plates as shown in Fig. 7(c). This material had approximately 80 vol\% of randomly interlocking crystals of mica. Generally, the bulk microstructures consisted of plate-like structures as shown in Figs. 7(c) and 7(d).

\section{Mechanical properties and machinability}

The three-point bending strength data were analyzed in a double-logarithmic Weibull plot (Fig. 8), where the slope and $\mathrm{x}$-axis intersection of the fitting curve corresponds to the Weibull modulus, $m$, and the characteristic strength, $\sigma_{\mathrm{c}, 0}, \quad$ respectively. The characteristic strength is $176.61 \mathrm{MPa}$ and Weibull modulus of 17.80 as shown in Table 2. Three-point bending strength and Vickers hardness of GCF 4.0 is higher than $2 \mathrm{~A}^{8} \mathrm{M}^{22}$, however, lower than that of $3 \mathrm{~A} 7 \mathrm{M}^{22)}$. 
Table 3 Marginal gap width of inlay of GCF 4.0

\begin{tabular}{lc}
\hline Location & Marginal gap width $(\mu \mathrm{m})$ \\
\hline Occlusal & $88.37 \pm 35.45$ \\
Interproximal & $109.85 \pm 59.21$ \\
\hline
\end{tabular}

For acceptable machinability of a glass-ceramic, the brittleness index $(B)$ of the material should be less than $4.3 \mu \mathrm{m}^{-1 / 2}{ }^{20)}$. From Table 2 , it can be seen that GCF 4.0 is within this range and can be machined by conventional dental tools. The hardness of GCF 4.0 is $3.70 \mathrm{GPa}$ and is similar to that of human enamel (3.2 GPa), thus, it should not induce increased wear of the opposing contact tooth. Due to the large number of fine calcium-mica crystals and their interlocking microstructures, resistance to crack growth results in a relatively high $K_{I C}$ $(2.04 \mathrm{MPa} \sqrt{\mathrm{m}})$. On the other hand, $K_{I C}$ of enamel $(0.77$ $\mathrm{MPa} \sqrt{\mathrm{m}})$ is low resulting from easy fracture along the weak boundaries between the enamel rods ${ }^{5)}$.

\section{Fabrication}

The restoration was designed with the aid of a computerized design (CAD) by CEREC 3D software. The glass-ceramic blocks were then milled via a computercontrolled milling machine (CAM), for example, veneers, inlays, and crowns (Fig. 9(a)). The fracture behavior of GCF 4.0 allows this glass-ceramic to be machinable because the cleavage allows propagation of cracks to follow a path determined by the cutting tool (diamond bur). No microcracking was observed away from the cutting surface, however, strip lines (Fig. 9(a)) from the diamond bur were present on the machined surface were due to incomplete surface finishing. The mean surface roughness as described by the arithmetic mean roughness $\left(\mathrm{R}_{\mathrm{a}}\right)$ was $1.95 \pm 0.03 \mu \mathrm{m}$. The successive deformation caused by cutting was attributed to the degree of plasticity of the Ca-mica phase more like a ductile metal than a brittle ceramic ${ }^{24)}$. Moreover, the appearance of the restoration was an exact replica as the design shown in Figs. 9(b) and 9(c). The average gap sizes of the inlay were calculated for the occlusal surfaces $(88.37 \pm 35.45$ $\mu \mathrm{m})$ and interproximal surfaces $(109.85 \pm 59.21 \mu \mathrm{m})$ as shown in Table 3 . Both the mean marginal gap size along the occlusal surfaces and the interproximal surfaces of the GCF 4.0 were within clinically accepted standards $(<120 \mu \mathrm{m})^{25)}$.

\section{DISCUSSION}

This mica layers are connected to each other by alkaline earth ions. The weak bonding of these alkaline earth interlayer ions determine the mechanical properties of these layered structures ${ }^{5}$. For this reason, mica crystals posses excellent cleavages perpendicular to the $c$-axis. By contrast, fracture propagation across the basal plane is more difficult inducing fractures to the cleavage planes or mica-glass interfaces ${ }^{26)}$

The commercial mica glass-ceramic materials used for CAD/CAM, such as Dicor (tetrasilicic mica: $\mathrm{KMg}_{2.5} \mathrm{Si}_{4} \mathrm{O}_{10} \mathrm{~F}_{2}$ ) and Macor (fluorophogopite: $\mathrm{KMg}_{3} \mathrm{AlSi}_{3} \mathrm{O}_{10} \mathrm{~F}_{2}$ ) contain $\mathrm{K}^{+}$as the interlayer ions ${ }^{27}$. The glass-ceramic in this work contains $\mathrm{Ca}^{2+}$ as the interlayer ions and exhibits a higher strength than the $\mathrm{K}^{+}$interlayer glass ceramics due to the divalency of these interlayer alkaline earth ions.

Taruta et al. ${ }^{22)}$ investigated calcium-mica and fluorapatite glass-ceramic and found that $3 \mathrm{~A} 7 \mathrm{M}^{22)}$, composed of a large amount of fluorapatite crystals and with a finer calcium-mica microstructure, gave higher bend strengths and hardness than those of GCF 4.0 $(0.4 \mathrm{~A} 9 \mathrm{M})$ and $2 \mathrm{~A} 8 \mathrm{M}^{22)}$. Its machinability is inferior to the other materials because of the incomplete interlocking microstructure ${ }^{22)}$. The interlocking of the randomly orientated mica crystals is a crucial characteristic in developing good machinability in glass-ceramics ${ }^{5)}$.

Since the crystals are in mutual contact, a series of deflections, branching and often blunting of cracks absorb energy ${ }^{26)}$ allowing for good machining. GCF 4.0 contains the highest amount of mica resulting in the highest degree of interlocking.

The Weibull modulus $(m)$ describes the relative spread of strength values in an asymmetric distribution. The Weibull modulus of this glass-ceramic material approaches a value of 18 exhibited a large $m$ value. This good value of Weibull modulus demonstrates the greater clinical reliability and the small flaw size distribution in this material ${ }^{28)}$. The characteristic strength of this glassceramic is appropriate for a single unit of anterior or posterior protheses (e.g. veneers, inlays, onlays and crowns) according to ISO $6872: 1997(\mathrm{E})$. Nevertheless, the chemical solubility must be investigated to determine long term durability ${ }^{18)}$.

Boccaccini $^{20)}$ has proposed the brittleness index as a parameter for machinability evaluation. The brittleness index was given by the ratio of the hardness $(H v)$, which quantifies the resistance to deformation, to the fracture toughness $\left(K_{I C}\right)$, which quantifies the resistance to fracture. The correlation of both of these phenomena is preferred over hardness and toughness considered separately in order to predict the machinability of glassceramics. The machinability of restorative dental materials should similar to that of human enamel. The GCF 4.0 can be machined comparable to human enamel according to this index.

The CAD/CAM system is an ideal system for producing highly accurate dimensions needed for dental restorations. This system offers one solution for the production of restorations by machining industrially fabricated ceramic blocks to reduce number of bulk defects ${ }^{27)}$. The fine grain size allows for good resolution in machining ${ }^{5)}$ for this material, although as with any machining processes, the dental burs initiate surface damage that could reduce the potential strength. To overcome this smooth surface finishing by polishing should be used as a final step to remove the larger surface flaws, reducing surface imperfections, including grooves 
and fissures ${ }^{29)}$ and thereby increasing reliability.

In order to produce acceptable colors for restorative dental glass-ceramics, colorants should be yellow to yellow-red in the crystallized product ${ }^{30)}$. The control of translucency and color shade needs to be addressed. Long term durability should also be studied in accordance with ISO $6872: 1997(\mathrm{E})^{18)}$. This standard indicates that core ceramic materials must have a chemical solubility less than $2000 \mu \mathrm{g} / \mathrm{cm}^{2}$ and for a body ceramic that is in direct contact with oral environment, it should be less than $100 \mu \mathrm{g} / \mathrm{cm}^{2}$.

\section{CONCLUSION}

The GCF 4.0 glass-ceramic containing calcium mica and fluorapatite crystal as dominant crystalline phases was found to be appropriate for the application of a machinable dental ceramic due to its good machinability and appropriate strength. A large Weibull modulus $(m)$ value suggests a reliable structural material. These properties, along with a useful fracture toughness, allowed for the material to be used with CAD/CAM to produce a prosthesis. According to ISO 6872 : 1997(E), the mechanical properties are proper for single unit anterior or posterior prostheses.

\section{ACKNOWLEDGMENTS}

The authors appreciate the assistance of Asst. Prof. Dr. Suchit POOLTHONG and Asst. Prof. Dr. Sirivimol SRISAWASDI, Department of Operative Dentistry, Chulalongkorn University as well as Asst. Prof. Dr. Kallaya Suputtamongkol, Department of Prosthodontics, Mahidol University in fabricating the glass-ceramic blocks by CAD/CAM technique with CEREC 3 software, and also thank Materials Innovation Center, Faculty of Engineering, Kasetsart University Research and Development Institute, and the Graduate School Kasetsart University, Kasetsart University for all supports and funding for experiments and publishing in international journals.

\section{REFERENCES}

1) Grossman DG. Cast glass ceramic. Dent Clin N Am 1985; 29: 725-739.

2) Thompson JY, Stoner BR, Piascik JR. Ceramics for restorative dentistry. Mater Sci Eng 2006; 27: 565-569.

3) Yin L, Song XF, Song YL, Huang T, Li J. An overview of in vitro abrasive finishing \& $\mathrm{CAD} / \mathrm{CAM}$ of bioceramics in restrorative dentistry. Int $\mathrm{J}$ Mach Tool Manu 2006; 46: 1013-1026.

4) Henry J, Hill RG. The influence of lithia content on the properties of fluorphlogopite glass-ceramics. I. Nucleation and crystallisation behaviour. J Non-Cryst Solids 2003; 319: 1-12.

5) Qin F, Zheng S, Luo Z, Li, Y, Guo L, Zhao Y, Fu Q. Evaluation of machinability and flexural strength of novel dental machincable glass-ceramic. J Dent 2009; 37: 776-780.

6) Liu Y, Xiang Q, Tan Y, Sheng X. Nucleation and growth of needle-like fluorapatite crystals in bioactive glass-ceramics. $J$ Non-Cryst Solids 2008; 354: 938-944.
7) Beall GH. Structure, Properties, and applications of GlassCeramics, In: Freiman SW, Hench LL, editors. Advances in nucleation and crystallization in glasses. Columbus, Ohio: The American Ceramic Society, Inc; 1971. p. 251-261.

8) Hoda SN, Beall GH. Alkaline Earth Mica Glass-Ceramics. In: Simmons JH, Uhlmann DR, Beall GH, editors. Advances in Ceramics Vol.4, Nucleation and crystallization in glasses. Columbus, Ohio: The American Ceramic Society, Inc; 1982. p. 287-300.

9) Uno T, Kasuga T, Nakajima K. High strength mica containing glass-ceramics. J Am Ceram Soc 1991; 74: 3139-3141.

10) Chaysuwan D, Bubb N, Maskill S, Hammond C, Hill R, Wood D. Development of high-strength machinable glass ceramics for dental applications. Proceedings of Incorporating the XIVth International Symposium on Non-Oxide and Novel Optical Glasses (ISNOG XIV); 2004 Nov 7-12; Florida, USA. Glass\&Optical Materiala Division Fall; 2004. p.54.

11) Chaysuwan D, Chongsaguan J, Bumrungvej T. Machinable glass-ceramics for dental application. Proceedings of the Sixth Asian BioCeramics Symposium (ABC2006); 2006 Nov 7-10; Bangkok, Thailand. Asian Bioceramics; 2006. p.29-32.

12) Keawsupsak K, Tucksanont P, Supanaroj T, Bai J, Chitwatcharakomol T, Chaysuwan D. Development of mica-based glass-ceramic with fluorapatite variation for restorative. Proceeding of the 22nd International Symposium on Ceramics in Medicine; 2009 Oct 26-29; Bioceramics22; 2009. p.783-786.

13) Marotta A, Buri A, Branda F. Nucleation in glass and differential thermal analysis. J Mater Sci 1981; 16: 341-344.

14) Kissinger HE. Variation of peak temperature with heating rates in differential thermal analysis. J Chem Phys 1956; 57: 217-221.

15) Augis JA, Bennett JE. Calculation of the Avrami parameters for heterogeneous solid state reaction using a modification of the Kissinger method. J Res Nat Bur Stand 1987; 13: 283-292.

16) Avrami M. Kinetics of phase change. J Therm Anal 1939; 7: 1103-1112.

17) Marotta AB. Nucleation and crystallization of $\mathrm{Li}_{2} \mathrm{O} \cdot 2 \mathrm{SiO}_{2}$ glass- a DTA study. In: Simmons JH, Uhlmann DR, Beall GH, editors. Advances in Ceramics Vol.4, Nucleation and Crystallization in Glasses. Columbus, Ohio: The American Ceramic Society, Inc; 1982. p.146-152.

18) International Organization for Standardization. ISO 6872:1997(E). Dental ceramics. Switzerland.

19) Baik DS, No KS, Chun JS, Yoon YJ, Cho HY. A Comparative Evaluation Method of Machinability for Mica-based glassceramics. J Mater Sci 1995; 30: 1801-1806.

20) Boccaccini AR. Machinability and brittleness of glassceramics. J Mater Process Tech 1997; 65: 302-304.

21) http://www.sunmedical.co.jp/english/productinfo/superbond_ cb, March 30, 2009.

22) Taruta S, Mukoyama K, Saori S, Kitajima K, Takusagawa NI. Crystallization process and some properties of calcium mica-apatite glass-ceramics. J Non-Cryst Solids 2001; 296: 201-211.

23) ASTM Standard E112-96, Standard test methods for determining average grain size; 2004

24) Hongda C, Marion A, Kalceff, Lawn BR. Deformation and fracture of mica-containing glass-ceramics in Hertzian contacts. J Mater Res 1994; 9: 762-770.

25) McLean JW, Von Fraunhofer JA. The estimation of cement film thickness by an in vivo technique. Br Dent J 1971; 131: 107-111.

26) Habelitz S, Carl G, Russel C, Thiel S, Gerth U, Schnapp J-D, Jordanov A, Knake H. Mechanical properties of oriented mica glass-ceramic. J Non-Cryst Solids 1997; 220: 291-298.

27) Thompson JY, Bayne SC, Heymann HO. Machnical properties of a new mica-based machinable glass ceramic for CAD/CAM restorations. J Prosthet Dent 1996; 76: 619-623. 
28) Tinschert J, Zwez D, Marx R, Anusavice KJ. Structure reliability of alumina-, feldspar-, leucite-, mica- and zirconiabased ceramics. J Dent 2000; 28: 529-535.

29) Chen HY, Hickel R, Setcos JC, Kunzelman K-H. Effect of surface finish and fatigue testing on the fracture strength of
CAD/CAM pressed-ceramic crown. J Prosthet Dent 1999; 82: 468-475.

30) Sun Y, Wang Z, Tain J, Cao X. Coloration of mica glassceramic for use in dental CAD/CAM system. Mater Lett 2002; 57: 425-428. 